\title{
Translating English Existential 'there' Sentences into Arabic: A Text-based Analysis
}

\author{
Irfan Said \\ Department of English, College of Arts and Letters, \\ Cihan University, Erbil, Iraq
}

\begin{abstract}
:
English existential 'there' lacks equivalent in many languages, yet it has attracted the attention of linguists working within contrastive linguistics and translation studies. The aim of the present paper is to investigate how translators deal with English 'there' sentences in two translated Arabic texts. The method adopted in the study is a descriptiveanalytic one. In Arabic the words 'hunaaka' and 'tammata' are usually used to render English 'there' ; however, the data of the study show that in many cases translators avoid using these two words. The flexibility of word order in Arabic, in addition to the use of full lexical verbs , more frequently than English does in 'there' sentences, help to translate these sentences adequately into Arabic. It is also found that syntactic restrictions are not the only reason for the fact that many 'there' sentences are not translated using 'hunaaka' and ' tammata'; the discourse and stylistic levels, play a role in the translator's decision to use other means. In some cases, the use of 'hunaaka /tammata' is shown to be optional and in other cases to be obligatory, unless an alternative construction is produced. Major translational changes affecting the information structure of the texts, are not found in the target language.
\end{abstract}

Key words: Arabic existentials, Arabic-english translation, existential -there , tammata, hunaaka

Cites as: Said, I. (2019). Translating English Existential 'there' Sentences into Arabic:

A Text-based Analysis. Arab World English Journal for Translation \& Literary Studies, 3 (2). 177- 191. DOI: http://dx.doi.org/10.24093/awejtls/vol3no2.15 


\section{Introduction}

English existential 'there' as in:

(1) There is a pencil on the table.

lacks equivalent in many languages, yet it has attracted the interest of linguists working within contrastive linguistics and translation studies ( see Creissles,2014). In Arabic to say:

(2) qalam -un fawqa-l-tawiläi

pencila on the table

'A pencil is on the table'.

is usually unacceptable since it starts with an indefinite expression. So, a structure is used in which the locative phrase 'fawqa -1- țawilati' is placed before the indefinite noun phrase 'qalam-un':

(3) fawqa - l-țawilä̈i qalam-un

on DEF table pencil a

'There is a pencil on the table.'

In modern standard Arabic the words 'hunaaka' and 'tammä̈a' are usually used to translate the English 'there' sentences into Arabic, though the present study will show that they are not the preferred translations in many cases. The purpose of this study is to answer the following question: how are the different roles of the English existential 'there' sentences dealt with in Arabic;particularly,how translators treat 'there' themes when translating into Arabic which has a different information structure system from English? It is hypothesized that the functions that are attributed to the English existential 'there' can be expressed in Arabic in a variety of ways.

\section{Data collection}

The data of this study consist of two English books translated into Arabic by two professional translators. The first one entitled 'Axel's Castle', Fontana edition, 1976 is an expository text concerned with the imaginative literature. It is written by the critic Edmund Wilson(henceforth:Wilson), translated by Jabra I. Jabra(henceforth: Jabra) and published by Dar Al-Hurriya,Baghdad, 1976. The second book is a narrative text, D.H.Lawrence's novel 'Women in Love'(henceforth:Lawrence),Penguin edition, 1960. It is translated by Amjad Hussein (henceforth: Hussein) and published by Al-Ma'moon House for Translating and Publishing, Baghdad, 1990.

\section{Existential 'there' sentences in English}

English has two kinds of 'there': existential and adverbial. For example, in:

\section{(4) There is a chair over there.}

The first 'there' is a dummy word, a mere place holder, used to introduce the existence of the indefinite noun phrase 'a chair'; and the second one is an adverb. This clearly shows that the first 'there' functions as the organizer of the message in (4). Collins (2001, p. 1) states that"existentialthere sentences have been characterized as serving a 'representative'function, drawing attention to an element that comes into view or to the attention of the addressee."

According to Quirk et al., (1985, pp.1402-08) existential 'there' sentences in English are, generally, of these types:

A. there + be + indefinite $\mathrm{NP}+$ place

Arab World English Journal for Translation \& Literary Studies 
(5) There was silence in the room. (Lawrence, p.48)

B. there + be + indefinite NP

(6) There was a pause (Lawrence,p.69)

C. there + be $+\mathrm{NP}+$ relative clause

(7) There was a thistle which pricked him vividly. (Lawrence, p. 119)

D. there + be $+\mathrm{NP}+$ to infinitive

(8) There was no need to be nasty about it (Lawrence,p.106)

E. there + be + definite NP

(9) How could we get there? - Well, there's the trolley (Rando \&Napoli, p 306)

F. there + a verb other than $b e+\mathrm{NP}$

(10) In 1873, there had appeared in Paris, a book of poems called 'le Amous Jaunes'(Wilson, p. $80)$.

\section{Existential sentences in Arabic}

As mentioned in the introduction, in modern standard Arabic the words 'hunaaka' and 'tammä̈a' are used in many cases to render the English existential 'there'. 'Hunaaka' and 'tammä̈a' are almost synonymous, but it seems that 'tammä̈a' sounds more formal than 'hunaaka'. Aziz(1995,p. 49) states that "The dummy hunaaka was introduced at the beginning of this century [20 $0^{\text {th }}$ century] by translators, under the influence of the European languages, much to the chagrin of the purists, who have been fighting a losing battle against this use of hunaaka".Arab grammarians consider 'hunaaka' and 'tammä̈a' referring expressions(literally:referring nouns) and adverbs at the same time (see Hassan, 1974,p. 295). For example:

(11) sirtu min huna 'la hunaaka.

walked-I from here to there

'I walked from here to there.'

(12) tammä̈a hall -un li hadihi -l-muškilä̈i.

there solution - NOM for this DEF problem

'There is a solution for this problem.'

Arabic has a rather flexible word order and this enables it to express existentials by exploiting this characteristic. As said earlier, in Arabic a sentence starting with an indefinite noun phrase like (2) is unacceptable. Instead, the word order is reversed to get (3). This is in agreement with the general restriction on existential sentences concerning an indefinite expression at the beginning of a sentence. The verb 'yǔgadu=exist', and other full lexical verbs giving a sense of existence, are also used to refer to something or someone as will be shown later.

\section{Information structure}

Many linguists have dealt with the different aspects of the English existential sentences. The present study adopts the version of analysis presented in Quirk et al., (1985) which draws upon the idea of 'given', 'new', and 'focus' information in describing such sentences. Information structure, or 'information packaging', denotes the ways in which thoughts are packaged into sentence structures to express information progress in discourse (Doherty, 2002). It shows how the status 
of information is encoded in the interaction of grammar and cognitive systems. For instance, it is possible for one meaning to be expressed by a number of different structures, as is seen in the following examples from English and Arabic respectively:

(13) A. The boy was chasing the girl.

B. The girl was chased by the boy.

C. It was the girl the boy was chasing.

D. What the boy was chasing was the girl.

(14) A. ištaraa zayd-un kitab-an bought-he zayd-NOM book-ACC

'Zayd bought a book.'

B. zayd-un ištaraa kitab-an zayd-NOM bought-he book-ACC

'Zayd, he bought a book.' (i.e., Zayd, not someone else)

C. al-kitab-u zayd-un ištaraa-hu

DEF-book-NOMzayd-NOM bought-it

'The book, Zayd bought it.'

D. al-kitab-u ištaraa-hu zayd-un

DEF-book-NOM bought-it zayd-NOM

'The book, Zayd bought it.'

E. zayd-un kitab-aništaraa

zayd-NOM book-ACC bought

'Zayd, it was a book that he bought.'

F. kitab-an ištaraa zayd-un

book-ACC boughtzayd-NOM

'A book, Zayd bought.'

G. ištaraa kitab- an zayd-un bought-he book-ACC zayd-NOM

'It was a book that Zayd bought.'

Examples (13) and (14) reveal that English and Arabic differ in selecting their information items and structuring them.

6. Sampling and statistics

Since two texts are used in this study, I will start by examining them and then present text-derived statistics on the translation of 'there' sentences into Arabic. I will mainly look at how many 'there' instances are translated into Arabic using 'hunaaka', 'tammä̈a', word order, 'yuğadu', and other lexical verbs indicating 'existence'. As the number of words in 'Women in Love' is more than the number of words in 'Axel's Castle', only the first seventeen chapters of Lawrence's novel are examined in order to get approximately similar sizes of the two texts. Table1) displays the frequency of 'there' sentences in the two texts.

Table1. Frequency of 'there' sentences in the two English texts

Arab World English Journal for Translation \& Literary Studies

ISSN: 2550-1542 | www.awej-tls.org 
AWEJ for Translation \& Literary Studies Volume, 3 Number 2. May 2019

Translating English Existential 'there' Sentences into Arabic

Said

\begin{tabular}{|l|l|l|l|}
\hline Texts & $\begin{array}{l}\text { No. of words } \\
\text { (approx.) }\end{array}$ & 'There' instances & $\%$ \\
\hline Lawrence & 77,400 & 265 & 0.34 \\
\hline Wilson & 77,000 & 63 & 0.08 \\
\hline
\end{tabular}

Table 1indicates that existential 'there' is used in the narrative text more than in the expository text. For the purpose of this study, 100 instances of the translated 'there' sentences ( 50 from each text) are selected covering all the existential types in Arabic.

\section{Data analysis}

The two selected samples of 100 instances of 'there' constructions are translated into Arabic using: 'yuğadu' and other lexical verbs 49 times, 'hunaaka' 24 times, 'țammä̈a' 14 times, and the word order device 13 times. Table (2) illustrates these results.

Table2Types of existentials in the Arabic texts

\begin{tabular}{|l|l|l|l|l|l|}
\hline Text & \multicolumn{2}{|l|}{$\begin{array}{l}\text { No. of instances of 'yuğadu' } \\
\text { and other lexical verbs }\end{array}$} & hunaaka & tammäa & word order \\
\hline \multirow{2}{*}{ Jabra } & $y u \check{g} a d u$ & $\begin{array}{l}\text { other lexical } \\
\text { verbs }\end{array}$ & $11=22 \%$ & $6=12 \%$ & $9=18 \%$ \\
\cline { 2 - 6 } & $3=6 \%$ & $21=42 \%$ & & $8=16 \%$ & $4=8 \%$ \\
\hline Hussein & $6=12 \%$ & $19=38 \%$ & $13=26 \%$ & 8 & $13=100$ \\
\hline Total & 9 & 40 & 24 & 14 & \\
\hline
\end{tabular}

Table2reveals that the Arabic existentials: 'hunaaka', and 'tammä̈a', constitute only $38 \%$ of the data, whereas the exploitation of other devices such as full lexical verbs and word order constitutes $62 \%$. This fact indicates that in the majority of cases, the two translators avoid the use of 'hunaaka' and 'tammä̈a'. In what follows, I will examine how each of the devices mentioned in Table2is dealt with in the two texts under study.

\subsection{1. 'Yuğadu'}

The verb'yuğadu= exist' and its variant morphological forms (tuğadu, wağadna,nağidu...etc), constitute $6 \%$ in Jabra and $12 \%$ in Hussein,i.e., $18 \%$ in the 100 instances. Examples:

(15) They walked on for some way in silence, under the trees.Then he said slowly, as if afraid: 'There is life which belongs to death, and there is life which isn't death' (Lawrence,1960, p. 208). Saraa ba'ḍa- $l$ - masafä̈i șamit-ayni tạhta - l-ašğari tumma qala walked-they some DEF distance silent-both under DEF trees then saidmuta'niyan ka'na-hu h̆ha'f:tuğadu hayä̈-un tậhusu - $l$ - mawta wa tuğadu 
slowly as if-he afraid exist life-NOM belong DEF death and exist hayä̈-un laysat mawt-an

life NOM not death ACC (Hussein, 1990 p. 343)

'...there exists life which belongs to death, and there exists life which is not death.'

In (15), it is possible to use 'hunaaka' or 'țammä̈a' instead of 'tuğadu' (fem. form of 'yuğadu'), but it seems that the translator prefers 'tuğadu' for both instances of the 'there' in order to render faithfully the essence of the original English sentence.

(16) 'If there is no love, what is there?' she cried almost jeering (Lawrence,p.162)

hatafa-t bima yašbahu-l-istihza'a in lam yakun hunaaka hub-un fama

cried-she as resemble DEF jeering if not is there love-NOM what

- l- ladi yuğadu?

DEF that exist (Hussein,1990, p. 269)

'... if there is no love, what is there?'

The second 'there' in (16) is rendered as 'yuğadu' apparently to avoid the repetition of 'hunaaka', and also to emphasize the content of the question: what is there? as 'yuğadu' explicitly expresses 'existence'. What is interesting here is that 'yuğadu' in this position can't be replaced by 'tammä̈a' without reorganizing the structure to get:

'in lam yakun hunaaka hubun, fa tammä̈a mada?

if there is no love, then what is there?'

(17) And whereas in 'Ulysses' there is only one parallel, in this book there is a whole set (Wilson,1961,p. 187).

Wa baynama wağad-na fi yulsees muwaziy - an waḥid-an nağidu fi hada:

and whereas found we in Ulysses parallel ACC one ACC we find in this

-l-kitab-l- ğadid mağmu 'a mutakamila min-l-muwaziyati.

DEF book DEF new set whole from DEF parallels (Jabra, 1976,p. 183).

'And whereas we found in 'Ulysses' one parallel, we find in this new book a set of parallels" In (17), the structure of the English sentence is:locative+there+be+NP; it is related to the normal pattern: there+be+NP+locative. In the Arabic version, we observe that 'nağidu=we find' precedes the locative phrase 'fi had $a$-l-kitab=in this book' obviously to emphasize the core information element,i.e., 'this new book'.I think this method aids the information to flow effectively.

\subsubsection{Other lexical verbs}

Table 2 demonstrates that $40 \%$ of 'there' sentences in the sample texts are translated by using full lexical verbs indicating, explicitly or implicitly, appearance or existence on the scene (see Breivik,1981:18). Most of these verbs are similar to the lexical verbs used, instead of 'be' in the English 'there' sentences. The following are examples of such verbs used in the texts without resorting to 'hunaaka'or 'tammä̈a.

(18) Then, sure enough, there came a note from him, asking if she would come to tea with Gudrun to his rooms in town (Lawrence , p., 160).

tumma ta'akada-l-amru id waradat risalä̈-un min-hu yad $u$-ha fi-ha li

Arab World English Journal for Translation \& Literary Studies

ISSN: 2550-1542 | www.awej-tls.org 
then sure DEF matter as came letter NOM from him asking her in it to tanawili a šayifi maskani-hi bi-l-madinä̈i mustașhibä̈-an gudrun have DEF tea in house his in DEF town with ACC Gudrun (Hussein,.265).

'Then the matter became sure, as a letter came from him inviting her and Gudrun to tea at his room in town.'

In (18), the particle ' $\mathrm{id}=$ as ' together with the verb ' waradat=came ' replaces 'there'. In Arabic, this particle usually introduces a verbal element,i.e., it has a representative function similar to that of 'there' in English.

(19) There had already set in, about the middle of the century, quite independent of the theory of Evolution a reaction against the sentimentality and the looseness of Romanticism,...(Wilson,,p., 13).

fa fi awasiți-l-qarni ahaḍa yatabalwaru radu filin mustaqilan $n$

in middle DEF century began crystallize reaction independent from nazariyaẗi- $l$ - tațawiri wa- $l$ - irtiqa' dida miuíati - $l$-romansiyä̈i theory DEF evolution and DEF rising against sentimentality DEF romanticism wa halhalati -ha and looseness its (Jabra,p.13)

'In the middle of the century, a reaction began to crystallize, independent...' A reordering is taking place in (19). The phrase 'fafiawasiti-l- qarni=in the middle of the century' is fronted as a theme. Quirk et al., (1985) define thematic fronting as "the achievement of marked theme by moving into initial position an item which is otherwise unusual there." $(\mathrm{p}, 1377)$ In Arabic, as said in section (1), this structure helps to avoid starting the sentence with an indefinite expression. The verb 'yatabalwaru=crystalize' is exploited to embody the existence of ' $r a d u f i$ ' lin=a reaction'.

(20) There is a conflict here which cannot be evaded and Yeats, even in his earliest period, is unceasingly aware of this conflict (Wilson,p.34).

Huna yakmunu șirà -un la nastați u tağanubu-hu wa yeats hatta fi awali here exist conflict NOM not can we evade it and Yeats even in early bawakiri-hi yaš ŕ bi-hi dunama inqița

period his he feel of it without ceasing (Jabra,p.34). 'Here exists a conflict which we cannot evade...'

In (20), the original English sentence is basically of this type: there+be+indef.NP, whereas the rendered version is of the type: place+a lexical verb+indef.NP. The locative 'huna=here' in the initial position serves to avoid using an indefinite expression at the beginning of a sentence, but it also makes a change in the information structure. In the English sentence, 'a conflict' is considered as the given information, and 'here' as the new one, whereas in the Arabic sentence, 'huna' is the given information and 'șira ' $u n^{\prime}$ is the new. In this text, the translator resorts to the verb 'yakmunu=exist' as it plays a major role in showing the existence of 'a conflict'.

(21) There was a shout from the people (Lawrence, p.20).

Arab World English Journal for Translation \& Literary Studies 
fa -intalaqa hutaf-un min-l- ğami $i$

particle came shout NOM from DEF all (Hussein,p.34).

Here, the characteristic of Arabic as being basically a verb initial language is invested by using the particle ' $f a$ ' plus the verb 'intalaqa=came'. This particle is used to introduce an element in a sequence and together with the verb serves as a point of departure from which the sentence is developed toward the real subject: 'hutaf-un=shout'.

(22) Yet, there has never been a poet who enjoyed the sensuous world with more gusto than Valery or who solidly bodied it forth (Wilson,p.65).

Wa ma 'a dalika fa la ála - na la nalqa ša ra -an ahara yatamata $u$ and with that part. perhaps we not find poet ACC another enjoy

b -l-álami hissi bi-hararä̈n ašadu min hararä̈i valery aw șawara prep. DEF world sensuous with warmth more from warmth Valery or pictured

-hu bi-tağasudin aqwa

it with depiction stronger ( Jabra,p.64)

'Yet, perhaps we don't find another poet...'

In (22), the word 'nalqa=we find' replaces 'there'. But this option for 'nalqa' with only the negative particle ' $l a=n o$ ' makes the English 'never' lose its emphatic sense in Arabic. However, the information structure of the original sentence is almost maintained.

\subsection{Hunaaka}

'Hunaaka' is found 13 times (26\%) in Hussein and 11 times (22\%) in Jabra. Examples (23-26) show how this word is used.

(23) At these two opposite poles of the circle, human life is impossible: there exist only anti podal types of supernatural beings. But along the circumference of the circle, between these two ultrahuman poles, there occur twenty-six phases which cover all possible types of human personality (Wilson,p.47).

wa . nda hadayn-l-quṭbayni min-l -da'ra takunu hayä̈u-l - insani

and at these DEF poles from DEF circle is life DEF human

mustahila wa laysa hunaaka ila aanmațun mutaḍada min ka'natin hariqa

impossible and not there only types anti from creatures super

walakin la muhit - $l$-da'ra bayna hadayn - $l$ - qutbayni-l-

conj. but on circumference DEF circle between these DEF poles DEF

hariqayni lil insane hunaaka situn wa šsuna marhalä̈-an tašmalu al-

super of human there six and twenty phase ACC cover DEF

anmața-l-mumkina kuluha lil šahsiya- $l$-insaniya

types DEF possible all of personality DEF human (Jabra,p.47).

'And at these two...there is only anti podal..., there are twenty-six phases...'

The first 'there' in (23) is translated using 'hunaaka' together with the negative particle 'laysa=not', though it is acceptable to translate the verb 'exist' by saying: 'tuğadu faqat anmațun mutadada=exist only anti podal types.' The second 'there' also realizes as 'hunaaka'+ NP, i.e., the verb 'occur' is not rendered and the resultant structure is similar to the English bare existential: 'There are twenty-six phases....' 
(24) 'There are my sons-in-law' she went on, in a sort of monologue.'Now Laura's got married, there's another.(Lawrence,p.27).

tumma maḍa - t tataḥadaț bima yašbahu -l-ḥadita ila-l-_dati hunaaka:

then went she talking in sort of DEF talking to DEF self there

așhar -i wa ha hiya laura qad tazawağ-t fa halla șihrun

sons-in-law my and now she Laura has married she conj.replaced son-in-law

ahar

another ( Hussein,p.45)

'Then, she went on in a sort of monologue, 'There are my son's-in-law and now Laura's got married, there's another son-in-law"

The first 'there' in (24) is rendered as 'hunaaka' but the second one as 'halla', a semantically rich verb referring to someone or something which comes into being. This verb is preceded by the conjunction ' $f a$ ' which, besides its usual function here (see 21), serves as a focusing element emphasizing the existence of a new son-in-law.

(25) 'Of course, there are children-' said Ursula doubtfully (Lawrence,p.9)

ama ursula fa qala-t murtabä̈-an hunaaka-l-atfalu tab'an

as for Ursula conj. said she doubtfully ACC there DEF children of course (Hussein,p.17)

'As for Ursula, she said doubtfully,"There are the children, of course."

In the source language, 'there' is preceded by the focusing phrase 'of course', whereas in the Arabic version the 'hunaaka' sentence is preceded by the focusing phrase 'am aursula=as for Ursula' and 'tab ' $a n=$ of course' is moved to the end. In spite of this minor change, the main focus of the sentence is maintained.

(26) 'To know, that is yours all.That is your life- you have only this, this knowledge',he cried.'There is only one tree; there is only one fruit, in your mouth(Lawrence,p.43).

fa hataf-a qa'l-an an tálami had̃a huwa anti kuliki hada conj.shouted-he saying ACC to know-you this is you all you this hayaruki la tamlukina siwa hada siwa hadihi-l-ma'rifa hunaaka choice-your not possess-you only this only this DEF knowledge there šăgarat-un waḥidä̈-un faqat tammä̈a tamarä̈-un wahidä̈-un faqat fi tree NOM one NOM only there fruit NOM one NOM only in famiki

mouth-your ( Hussein,p.70)

'...There is only one tree; there is only fruit, in your mouth.'

Again, in (26), 'there' is used twice. Here 'tammä̈a' can be replaced by 'hunaaka', but it seems that the translator tries to avoid the repetition of this word. However, there are cases where these two words can't be replaced by each other without making changes in the structure of the sentence (see 29).

\subsection{Tammä̈a}

As table (2) exhibits Hussein uses 'țammä̈a' 8 times (16\%) and Jabra, 6 times (12\%). Examples:

Arab World English Journal for Translation \& Literary Studies 
(27) 'There is', he asserts in his early essays on the symbolism of Shelley, "for every man some one scene, some one picture that is the image of his secret life, for wisdom first speaks in images..." (Wilson,p.40).

fi maqali-hi-l-mubakir ' $n$ ramziyaẗ šely nağidu - hu yaqulu li kulli

in essay his DEF early on symbolism Shelley we find him saying for every

imri'n tammä̈a mašhad-un waḥid-un mugamarä̈-un wahidä̈-un șurat-

man there scene NOM one NOM adventure NOM one NOM picture un waḥidat-un hiya șurä̈u hayati-hi - $l$ - hafiya li'anna - $l$ - hikmä̈a

NOM one NOM is picture life his DEF secret because DEF wisdom tantiqu awala-an bi - $l$ - șuwari

speak first ACC by DEF pictures (Jabra,p. 40 )

'In his early essays on the symbolism of Shelley, we find him saying: for every man, there is one scene...'

In (27), Wilson splits the 'there' sentence by inserting the focal clause 'he asserts...' In translation, Jabra thematizes the PP 'likuli 'mri'n=for every man' and presents the sentence as: $\mathrm{PP}+\underline{t} a m m a \ddot{t a}+\mathrm{NP}$. By this change, the translator creates a cohesive text in Arabic. Concerning the use of 'tammä̈a', one can consider it, together with 'hunaaka', an optional element here, since it is possible to translate the sentence without using them, a case preferred by the purists.

(28) There seemed a dual consciousness running in him. He was thinking vigorously of something he read in the newspaper, and at the same time, his eye ran over the surface of the life round him, and he missed nothing (Lawrence,p.58).

Kana tammä̈a fi qararä̈i nafsi-hi wa 'y-an 'la ma yaluh faqad kana

was there in side self him consciousness two seem part. was

yufakiru maliy-an fi šay'in ma qara'a-hufi a șahifä̈i wafi

he thinking vigorously ACC in something read he it in DEF newspaper and in

-l-waqti ynihi kanat 'ynu-hu taḥumani ' ala awğuhi-l-hayäti hawla-hu

DEF time same was eye his ran over on surface DEF life round him

wa lam yafut -hu ayušay'

and notmissed him anything (Hussein,p.95).

'There seemed a dual consciousness in the depth of his heart....'

In (28), the phrase 'la mayaluh', the equivalent of the English verb 'seem', is movedto the end of the Arabic sentence, and 'kana=was' is used to show past tense. Again'tammä̈a' can be optional here,i.e., without it, the sentence reads: kana fi qararati nafsihi wa 'yan. In this case, the verb 'kana' embodies the sense of existence.

(29) There is a curious fascination about becoming gradually acquainted with a character whom we know only from the inside and from his dreams(Wilson,p.188).

tammä̈a siḥr -un garib -un naḥisu -hu bi 'tila'ina

there fascination NOM curious NOM we feel it by acquaint we

šay'an fa šay'an 'la nawaḥi šahsiyä̈-in la na 'rifu-ha illa min-l-dahili

gradually on aspects character GENnot we know it only from DEF inside

wa min ahlami-ha

Arab World English Journal for Translation \& Literary Studies 
and from dreams its ( Jabra,p.184)

'We feel a curious fascination by acquainting ourselves with a character...' Unlike (28), the use of 'tammä̈a' in (29) is obligatory. It can be replaced by 'hunaaka', but it cannot be omitted without changing the structure. For instance, it is possible to exploit the verb in 'nahisu=we feel' to get:nahisu bi sịnrin garibin bițila 'ina...'we feel a curious fascination by acquainting ourselves...'

\subsection{Word order}

The flexibility of word order in Arabic allows it to readjust the elements of a sentence in order to achieve different communicative effects, and also to avoid starting a sentence with an indefinite noun phrase (see example 2). Nine existential sentences (18\%) depending on word order are attested in Jabra and four (8\%) in Hussein. The following are examples of the use of this device in the sample texts.

(30) And there is more substance in Valery than in Mallarme'(Wilson,p.64).

wa fi valery madä-un aktaru mima fi malarme

and inValéry substance NOM more than in Mallarme'(Jabra,p.63).

'And there is more substance in Vale'ry than in Mallarme.'

In (30), the translator does not opt for 'hunaaka' or 'tammäta'. He prefers to reorder the elements of the sentence to avoid mentioning an indefinite phrase at the beginning of the sentence. Here, there is also a change in the information structure. The 'new' information of the original sentence is thematized as 'given' and the subject 'madä̈un=substance' is driven to the end as 'new' information.

(31) 'I'm not afraid of anything except black-beetles', said Minette, looking up suddenly and staring with her round eyes, on which there seemed an unseeing film of flame, fully upon Gerald (Lawrence,p.76).

qala-t minet innani la ut 'abu min ayi šay'ñ ada-l-hanafis -lsaid she Minnet I am not afraid from anything except DEF beetles DEF sud wa hiya tarfa' $u$ wağha-ha fuğ'at-an tuḥadiqu fi ğerald bi black and she lifting face her suddenly ACC staring at Gerald with kamili aynay-ha-l-mudawaratayni allatayni badat 'alayhima gašawä̈u full eyes her DEF round which seemed on them film lahab -in la tura

flame GEN not seen (Hussein, p.127)

'... on which there seemed an unseeing...'

Example (31) needs an extended context in order to understand how the readjustment of the linguistic elements helps to avoid using 'hunaaka' or 'tammata' for 'there'; rather it exploits the sense of existence in the word 'badat=seemed' to achieve what 'there' achieves in English. As a matter of fact, using 'hunaaka' with 'badat' is not possible, but 'tammä̈a' can be employed: '... allatayni badat 'alayhima tammä̈a gašawä̈u lahabin...', though it sounds rather clumsy. (32) There is a good deal in Dante's morality which he never got out of the scholastics as, for all we know,there may be a good deal in Lucretius which he never got out of Epicurus. (Wilson,p. $100)$

Arab World English Journal for Translation \& Literary Studies 
fi ahlaqiyati danti-l-katiru mima lam ya'hu $\underline{\text { dit }}$-hu qațan - $l$ inmorality Dante DEF a good deal which not get it never from DEF falasifa - l-madrasiyiin kama anna fi loqrits rubama-l-katiru philosophers DEF scholastics as emphatic in Lucretius may be DEF more mima lam ya'hud-hu qat 'an abiqur which not get it never from Epicurus (Jabra,p.100).

'In Dante's morality, there is a good deal which he never got out of scholastics as there may be a good deal in Lucretius which he never got out of Epicurus.'In (32), it is quite acceptable to use 'tammä̈a' or 'hunaaka', but the translator resorts to reordering the constituents of the sentence, a case in which the communicative core, the phrase 'fi ahlaqiyä̈i danti=in Dante's morality' is moved to the initial position as'given' information, and 'al katiru=a good deal' realizes as 'new' information. We also note here that the preposition ' $f i=i n$ ' embodies the sense of existence.

\section{Findings and discussion}

The data of this study have shown that English 'there' can be translated into Arabic using, mainly, the words 'hunaaka' and 'tammä̈a'. However, the sample examples of the 'there' sentences reveal that only $38 \%$ of these instances are rendered by using the above two words. The relative flexibility of word order in Arabic enables it to express the content of 'there' sentences by either reordering the elements of the sentence or using a rich lexical verb to refer to the existence of someone or something. The decision of the translator to use either 'hunaaka' or 'tammä̈a' may not be purely syntactic; rather, the discourse functions, the rhetorical, thematic or stylistic aspects, may play a role in this decision. Therefore, it seems that some of the functions which are characteristics of the English existential 'there' sentences can be displayed in Arabic using different strategies. For example, for (33), we can have more than one possibility concerning information structure, as shown in a, b, c, and d:

(33) 'There is something', he says, 'of an old wives' tale in fine literature (Wilson,p.40).

A. yaqulu"fi rawa' - $l$-adabi šay'un min hikayati-l-aga'zi"

he says in fine DEF literature something from tales DEF old wives (Jabra,p.4o). He says,"In fine literature, there is something of old wives' tales."

B. yaqulu"tammä̈a šay'un min hikayati-l- 'aga'zifi rawa' - $l$-adabi"

he says there something from tales DEF old wives in fine DEF literature.

He says, "There is something of old wives' tales in fine literature."

C. yaqulu " hunaakafi rawa' - l-adabišay'unmin hikayati-l - 'aga'zi":

hesays there in fineDEF literature something from talesDEF old wives.

He says, "There is in fine literature something of old wives' tales."

D. yaqulu yuğadu šay'un min hikayati-l- 'ağa'zi fi rawa' ' - l-adabi.

he says exist something from tales DEF old wives in fine DEF literature.

He says, "There exists something of old wives' tales in fine literature."

Sentence (33) could be translated as (a) in which Jabra renders 'there' exploiting the word order device. He moves the locative phrase 'fi rawa' ' $l$ - adabi=in fine literature' to the beginning of the sentence to become the 'given' information, and positions the phrase'say'un min hikayat-l'ağa'zi=something of old wives' tale' at the end as 'new' information. Another choice is (b) where

Arab World English Journal for Translation \& Literary Studies 
the role of 'given' and 'new' is reversed and 'hunaaka' stands for 'there'. In (c) 'fi rawa' '-l-adabi=in fine literature' is introduced by 'hunaaka' as 'given' information. Finally, in (d) the verb 'yuğadu=exist' is used to replace 'there'. What these possibilities show is that the translator has the choice to thematize any of the two phrases in (33), and also to use 'hunaaka', 'tammä̈a' or'yuğadu' for 'there', or do without them altogether.

Among other interesting cases in the translated data, the following attract attention.

First, cases of 'there-less' sentences in the source language which are translated using'tammä̈a'; and second, the cases where the use of 'hunaaka' and tammä̈a' is either obligatory or optional. Examples (34) and (35) illustrate these cases.

(34) The sisters were crossing a black path through a dark, soiled field. On the left, was a large landscape, a valley with collieries and opposite hills with cornfields and woods all blackened with distance, as if seen through a veil of crape. White and black smoke rose up in steady columns, magic within the dark air. Near at hand came the long rows of dwellings, approaching curved up the hill-scope, in straight lines along the brow of the hill (Lawrence,p.12).

kanat-l-uht - an ta áburani mamar-an aswad 'bra haqlin muẓlim - in was DEF sister two crossing path ACC black through field dark GEN mutasih tammä̈a 'alağihäti-l-yasari saq '-un wasi'-un wa soiled there on side DEF left landscapeNOM large NOM and wad - in $\underline{d}$ u manağimi faḥm-in wa tilal-in muqabila-ha fi -ha valley GEN with collieries GEN and hills GEN opposite them in them gabat-un wa huqulu hinta aḍfa bu'du -l-masafä̈i 'alay -ha woods NOM and fields grain added remoteness DEF distance on them lawn-an aswad ka'ana-ha tura' bra qina '-in min - l-kreb wa color ACC black as if they seen through veil GEN from DEF crape and kana duhan-un abyaḍ wa aswad yartafíu aliy-an fi a midat-in was smoke NOM white and black rise up ACC in columns GEN mustaqira $k$-sihri fi-l-hawa'-l-muzlimi wa tammä̈a an katab ta'ti steady as magic in DEF air DEF dark and there from near come a șufuf - $l-$ tawila lil masakini fi hutuț-in mustaqima 'ala tuli ğabhä̈ DEF rows DEF long of dwellings in lines GEN straight on along brow $-l-$ tali

DEF hill ( Hussein,p.21)

'The sisters were crossing a black path through a dark, soiled field. There was on the left...' ...'There was, near at hand, long rows....' What is happening in (34) is that the clause: 'on the left was a large landscape...' is a variation of the usual pattern, there+be+NP+locative: 'There was a large landscape on the left.' Hussein translates the clause by inserting 'tammä̈a' in the Arabic version primarily to mark the subject 'saq un'=landscape' as existing and also as a representative element. Furthermore, 'kana=was' could be used here instead of 'tammä̈a'. The order of the elements is acceptable since the indefinite noun phrase is not introduced at the beginning of the construction. The sentence beginning with 'near at hand...' is also translated by introducing it with 'tammä̈a', though without 'tammä̈a', it will read well. 
Again it seems that the use of 'tammä̈a' here serves to bring something to the reader's awareness.

(35) But in the newspaper office, for the first time, a general atmosphere begins to be created, beyond the specific minds of the characters, by punctuating the text with newspaper heads which announce the incidents in the narrative (Wilson, p. 167).

wa lakin nağid-u fi maktab-l-ğaridä̈i li awali marrä̈-in anna conj. but we find in office DEF newspaper for first time GEN emphatic

tammä̈a ğaw -an 'amma -an a ha there atmosphere ACC general ACC began DEF author create it

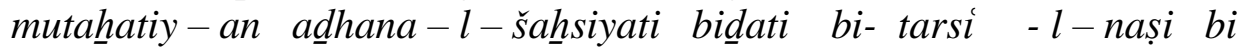
beyond ACC minds DEFcharacters specific bypunctuation DEF text with 'anawin ğara'diya tu linu hawaditi - l-qiṣati heads newspaper announce incidents DEF story (Jabra,p.165).

'But we find in the newspaper office, for the first time, that there is a general atmosphere the author began to create...'

In (35), the English passive form is translated as an active form in Arabic. Arabic, as a matter of fact, prefers the active form to the passive form, in many cases. The insertion of 'tammä̈a' here is optional since the phrase 'nağidu=we find', which gives the sense of existence, is used in the beginning of the construction. What is apparent here is that Jabra tries to emphasize the existence of the 'general atmosphere' in the office.

\title{
9. Conclusion
}

The present study has examined English existential 'there' sentences and how they are translated into Arabic. It is shown that these sentences can be rendered adequately not only by using words such as 'hunaaka' and 'tammä̈a', but also--and in many cases preferably--by means of other devices. In cases where the translator is free to choose between 'hunaaka'/'tammä̈a', among other devices, his decision not to use either of these words, must serve to present a better translation. This is carried out through first, exploiting the relatively flexible word order of Arabic; and second, using full lexical verbs more frequently than English does in 'there' constructions.It is found that the syntactic restrictions are not the only reason for the fact that many 'there' sentences are not translated using 'hunaaka' and 'tammä̈a', the discourse and stylistic levels play a role in the translator's decision to use other means. In some cases, the use of 'hunaaka'/'tammä̈a' is shown to be optional while in others to be obligatory, unless an alternative structure is produced.Major translational changes affecting the information structure of the texts, are not found in the target language. Finally, the analysis of the texts has revealed that compared with English, fewer existential sentences are found in Arabic.

\begin{abstract}
About the author
Irfan Said: is an Assistant Professor holding M.A. in linguistics from London University, and author of a number of articles in the fields of applied linguistics, second language teaching, and contrastive linguistics, and has translated a number of books from English into Arabic. From
\end{abstract}


1980 to 2010 he taught at Al Mustansiriya University of Baghdad. He joined Cihan University in 2010. ORCiD ID https://orcid.org/0000-0002-0086-8956

\section{References}

Aziz, .Y. (1995). Existential Sentences in Arabic-English Translation.Meta XL (1): 47-53.

Breivik, L. (1981). On the Interpretation of Existential There.Language 57: 1-25

Collins, P. (2001). "Some Discourse Functions of Existentials in English".Proceedings of the 2001 Conference of the Australian Linguistic Society. 1-6.htt://linguistics. Anu.edu.au/ALS2001/proceedings.html

Creissles,D.(May, 2014) "Existential Predication in Typological Perspectives". www.deniscreissels.fr./Creissels-Exist.Pred.accessed November 3,2014

Doherty, M.(2002). Language Processing in Discourse: A Key to Felicitous Translation. London: Routledge.

Hassan, A.(1974).Al Nahwu Al Wafi[A Comprehensive Grammar of Arabic].Vol.1, Tehran: Intisharat Nasir Khasraw.

Hussein, A. (1990). Nis'un As ikat ( translation ).Baghdad: AL-Ma'moon House.

Jabra,I. (1976 ). Qala't Aksil.( translation ). Baghdad : Dar Al Hurriya.

Lawrence,D.H. (1960 ).Women in Love. Harmondsworth: Penguin.

Quirk, R.,Greenbaum,S.,Leech,G.,\&Svartvik,J. (eds). (1985). AComprehensive Grammar of the English Language. London: Longman..

Rando, E.,\& Napoli,D., (1978). Definiteness in There-sentences.Language,54:300-313.

Wilson,E.(1961). Axel's Castle.Glasgow:Fontana.

Arab World English Journal for Translation \& Literary Studies 